\title{
Agricultural development in Ecuador: A compromise between water and food security?
}

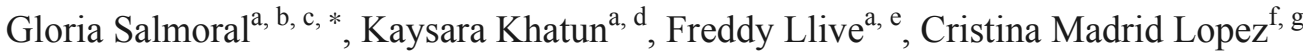 \\ ${ }^{a}$ Centro de Prospectiva Estratégica (CEPROEC), Instituto de Altos Estudios Nacionales, Ecuador \\ ${ }^{\mathrm{b}}$ Environment and Sustainability Institute, College of Engineering, Mathematics and Physical Sciences, University of Exeter, UK \\ ${ }^{c}$ Cranfield Water Science Institute (CWSI), Cranfield University, UK \\ d Environmental Change Institute, Oxford University Centre for the Environment, UK \\ e Ministry of Agriculture and Livestock, Ecuador \\ School of Forestry and Environmental Studies, Yale University, United States \\ ${ }^{\mathrm{g}}$ Institut de Ciencia I Tecnologia Ambientals, Universitat Autonoma de Barcelona, Spain
}

\section{A R T I C L E I N F O}

Article history:

Received 6 October 2017

Received in revised form 20 June 2018

Accepted 30 July 2018

Available online $\mathrm{xxx}$

Keywords:

Irrigation

National development policy

SWAT

Water metabolism

Socio-ecosystems

\begin{abstract}
A B S T R A C T
Ecuador is facing several threats to its food and water security, with over a tenth of its population currently undernourished and living in poverty. As a response, its government is incorporating new patterns of land use and developing regional water infrastructure to cope with the related challenges. In this study, we assess to what point these efforts contribute to integrated water and food security in the country. We investigated the period 2004-2013 in the most productive agricultural region - the Guayas river basin district (GRBD) and analysed the impacts of different scenarios of agricultural change on local water security. Our approach integrates MuSIASEM (Multi-Scale Integrated Analysis of Societal and Ecosystem Metabolism) with the hydrological SWAT model. Freshwater allocation is evaluated within all the water cycle from its source (natural systems) to the final users (societal systems). Water security is assessed spatiotemporally in terms of water stress for the population living in poverty. Water productivity is obtained in relation to agricultural production and nutrition. The multi-scale analysis shows that whereas at national level the median annual streamflow has a similar magnitude than rainfall stored in soil, these two parameters differ spatiotemporally at subbasin level. The study finds the greatest challenges in achieving water security is the south-east and central part of the GRBD, due to water scarcity and a larger population living in poverty. However, these areas are also simultaneously, where the greatest crop water productivity is found. We conclude that food production for both domestic consumption and market-oriented exports can be increased while meeting ecosystem water demands in all the GRBD regions except for the east. Our integration of methods provide a better approach to inform integrated land and water management and is relevant for academics, practitioners and policymakers alike.
\end{abstract}

(C) 2018

\section{Introduction}

Ecuador faces an important food security challenge, where approximately two million people - $11 \%$ of its population - are undernourished (FAO, 2017). In response, the government has implemented a legal reform that enshrines food sovereignty in its Constitution (República del Ecuador, 2008) following the principles of the National [Development] Plan for Good Living ${ }^{1}$-NPGL- (SENPLADES, 2013). The NPGL principles were incorporated into the Food Sovereignty Regime Organic Law of 2009, which sought to

\footnotetext{
* Corresponding author. Centro de Prospectiva Estratégica (CEPROEC), Instituto de Altos Estudios Nacionales, Ecuador.

Email address: gloria.salmoral@cranfield.ac.uk (G. Salmoral)

1 The National Plan for Good Living (Plan del Buen Vivir) comes out at four-year intervals (2009-2013 followed by 2013-2017). It is based on the indigenous Quechua concept of Sumak Kawsay (Buen Vivir) - a social paradigm - with objectives to 'better the quality of life of the population, develop their capacities and potential'.
}

avoid further monocultures and provides support for local farmers in the country. It has resulted in a raise of public investment in agriculture from \$93 million to \$268 million in the period 2003-2009 (Nehring, 2012). Despite legal efforts, public investment has not achieved local food security. On the contrary, it resulted in an increase in food production for export - a similar trend to other Latin American countries (Falconí et al., 2017).

The country has a large water endowment (average runoff of $1275 \mathrm{~mm}$ ), but it also presents an unequal distribution of water throughout regions and dry-wet seasons (CISPDR, 2014). A number of studies assess the physical and social drivers of Ecuador's water allocation within the water cycle. These include the effects of land use change (Espinosa and Rivera, 2016) and climate change (Molina et al., 2015) over freshwater provision or the contribution of paramo and aquifers retention capacity to baseflow (Guzmán et al., 2015). Research has also addressed the role of water user organisations in water management (Hoogesteger, 2013) and how institutional reforms strengthen water rights (Cremers et al., 2005) of local irrigation communities. Those studies focus mainly on small (i.e., 
$<500 \mathrm{~km}^{2}$ ) highland catchments from the Andean region, but to date and to the best of our knowledge there are no detailed spatiotemporal assessments of Ecuador that cover the distribution of available water resources, land use distribution (including irrigated areas) and their assigned water demand. More importantly, there are no studies on the areas with larger population densities of people living in poverty and where the most valuable crops are produced.

Distribution of available water resources will also likely be affected by future political decisions, related to changes in agricultural land patterns and water infrastructure, to ensure local and global food demand. The National Hydraulic Plan (period 2014-2035) and the National Plan for Irrigation and Drainage foresee an increase of the irrigated area by $53 \%$ (from 941,000 to $1,443,000$ ha) (MAGAP, 2013 ) and the existing reservoir volume by $90 \%$ (from $7690 \mathrm{hm}^{3}$ to $14,672 \mathrm{hm}^{3}$ ) (CISPDR, 2014), showing a strong connection between food and water security. Thus, for successful implementation over time, both agricultural development and water resource management must be coherent.

Integrated Land and Water Resources Management (ILWRM) is a scientific approach that highlights the connections between land and water management with the purpose of strengthen their interaction (Falkenmark et al., 2014). ILWRM builds on Integrated Water Management principles, but it provides a further step to environmental evaluations due to the considerations of water-land interactions at the local level (ibid). Indeed, local issues are more tractable because the systems co-exist in space (de Loë and Patterson, 2017). Despite the scientific consensus on the usefulness of the approach, ILWRM has had limited practical applications by water practitioners and lacks explicit consideration on environmental policies and development plans. For example, in Europe, the Water Framework Directive does not mention the relevance and effects of land use changes and practices on available water resources, which has resulted in a disconnection between agricultural and water policy objectives (Cabello and Madrid, 2014). Moreover, certain agricultural policy measures also determine land use management practices with effects on water allocation (Salmoral et al., 2017). This has also been the case in Ecuador, where national development plans, aim to increase food provision by including additional irrigated areas and changing crop patterns distributions, but there is no evaluation on the implications of such decisions on local water resources.

We focus on the Guayas river basin district (GRBD), as it is central to Ecuadorian water and food security. The study aims to answer the following questions: 1) What are the water needs for food security in the GRBD? 2) How does food security and the related agricultural development affect water security? The paper is organized as follows. Section 2 describes the selected case study and the ILWRM method, which combines MuSIASEM (Multi-Scale Integrated Analysis of Societal and Ecosystem Metabolism) (Giampietro et al., 2009) and the hydrological model SWAT (Soil and Water Assessment Tool) (Arnold et al., 1998). The applied indicators for food and water security links and water productivities are described and scenarios towards water and food security aims presented. Section 3 shows the main results, also including an evaluation of water and food security changes under the proposed scenarios. Section 4 discusses the relevance of our method and obtained multi-level results, and highlights the pressures on local water resources as well as the related implications of national development strategies for water and food security.

\section{Materials and methods}

\subsection{The Guayas river basin district}

The Guayas river basin district (GRBD) has a land area of $44,532 \mathrm{~km}^{2}$ (i.e., $16 \%$ of the country surface) and provides water resources for about 6 million inhabitants (i.e., $40 \%$ of the national population (INEC, 2015)). In 2010, the GRBD contained 380,840 ha irrigated land, which holds $57 \%$ of the national agricultural irrigated area (CISPDR, 2014; CISPDR, 2015). The GRBD is a humid tropical system comprising a rainy season from December to May and a wet one for the remaining months. There are precipitation variations from the north (2900-3100 mm) to the south (300-700 mm) (CISPDR, 2015). The GRBD contains the largest share of the national agricultural area for the region's most significant crops i.e., rice (96\%), banana (68\%), sugar cane (97\%), corn (55\%), coffee (33\%) and palm oil (19\%) (MAGAP, 2015) (Fig. 1; Table A1).

\subsection{Studying the water metabolism within ILWRM}

ILWRM analyses face an important 'issue of scale' (Cumming et al., 2006) because joint water-land analyses require the simultaneous adoption of different spatial-temporal scales. These differences are marked by water and land dynamics, with differing cycles and geographical boundaries. To address these factors this study assesses the water metabolism of socio-ecological systems from an ILWRM perspective using MuSIASEM (Giampietro et al., 2009).

MUSIASEM is a very powerful framework for the analysis of water use and its resulting impacts (Madrid-López et al., 2014; Madrid et al., 2013; Serrano-Tovar et al., 2014). However, it needs to be adapted to soil and land use dynamics for its application to ILWRM. Fig. 2 shows a chart that summarizes the adaptation and how the water metabolism of socio-ecosystems is conceptualized. The upper part connects the flows of water that reach the land surface and are available at the ecosystem level with those water flows used for food production. The lower level shows the structural organization of each system and the factors that transform them: climate change, ecosystem water requirements and food provision. Policy making is an important part of the metabolism, as it guides the biophysical flows that and has a direct influence over water and food security. Current policy goals have been used in the analysis to build scenarios. They are further developed in Section 2.5 .

\subsection{MUSIASEM-SWAT integration}

In this study, MuSIASEM serves as a framework in which (1971) Georgescu-Roegen's 'flow' and 'fund' concepts are used to structure the analysis. Funds refer to the components of the socio-ecosystems, which must be maintained (trees, people, river patterns, etc.) In general terms, a specific analytical tool is chosen according to the type of flow to be studied. The results of this analysis are contextualized with a study of the fund elements. As this study focuses on a river basin district, we use the hydrological model SWAT (Arnold et al., 1998). SWAT is able to simulate ecosystem water funds and societal water flows and integrate different spatiotemporal levels of water-land links. The model presents the capacity to combine hydrological components with a plant growth module, which is essential for the assessment of agricultural production in our study. However, it fails to tell the story behind those flows, thus the fund description of MuSIASEM is used for their contextualization. 

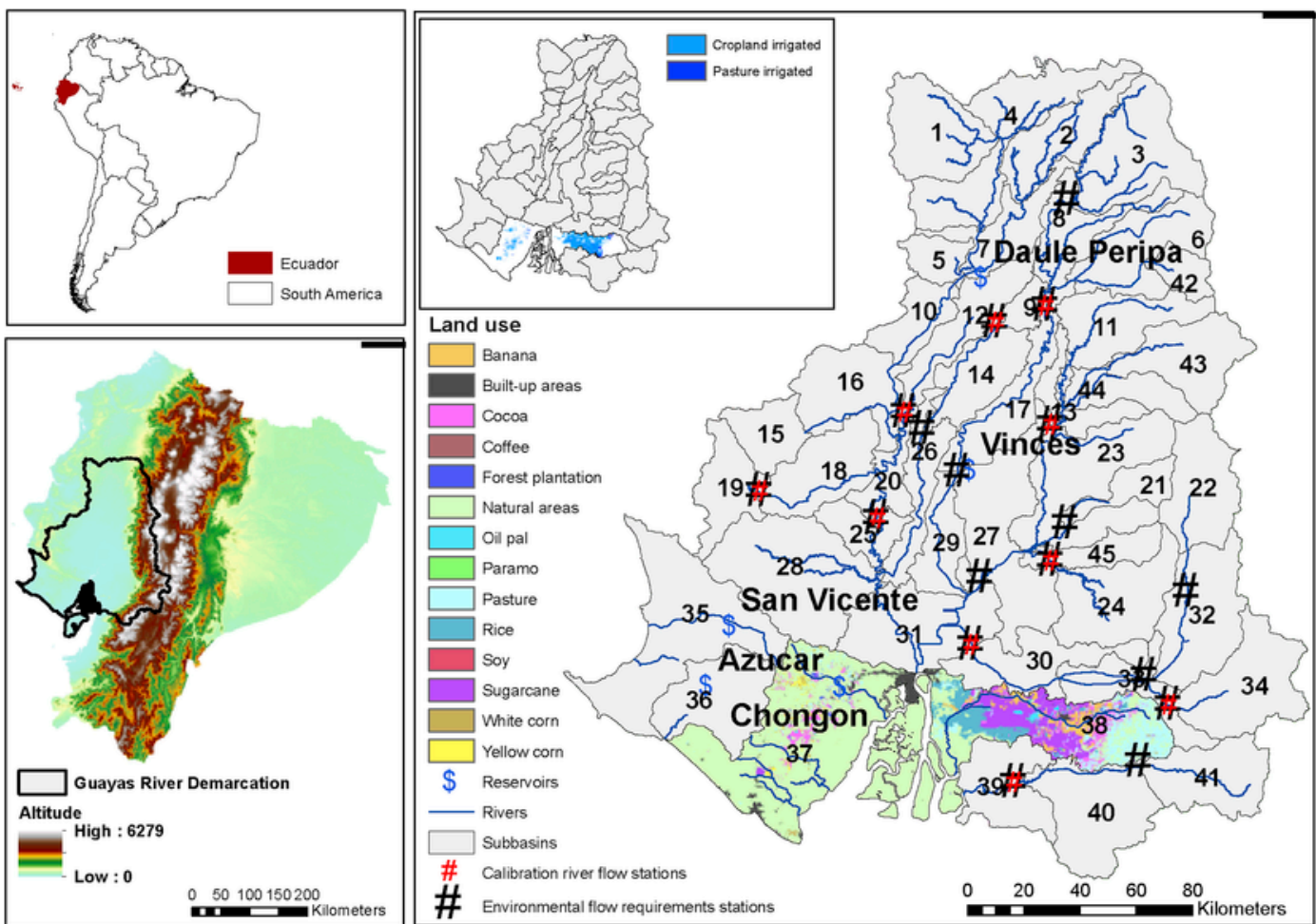

Fig. 1. Location of the Guayas river basin district. Main land use classifications and irrigated areas are shown.

\begin{tabular}{|c|c|c|c|}
\hline $\begin{array}{l}\text { Guayas } \\
\text { River Basin } \\
\text { District }\end{array}$ & Society (focus on food system) & Ecosystem & Earth Water Cycle \\
\hline 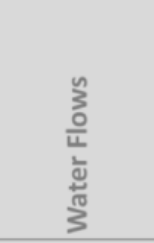 & $\begin{array}{l}\text { Water Use } \\
\text { Analysis of crop water } \\
\text { requirements }\end{array}$ & $\begin{array}{l}\text { Water availability } \\
\text { Analysis of Water } \\
\text { Socially Available }\end{array}$ & $\begin{array}{l}\text { Water Dynamics } \\
\text { Data on } \\
\text { Precipitation }\end{array}$ \\
\hline 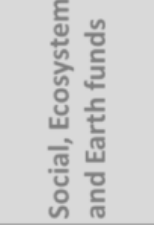 & $\begin{array}{l}\text { Policy decisions about land } \\
\text { use, food sovereignity and } \\
\text { international trade } \\
\text { Water \& Food Security }\end{array}$ & $\begin{array}{c}\text { Analysis of } \\
\text { Ecosystem water } \\
\text { needs }\end{array}$ & $\begin{array}{l}\text { Data on } \\
\text { Temperature } \\
\text { Climate }\end{array}$ \\
\hline
\end{tabular}

Fig. 2. The water metabolism of the food socio-ecosystem of the Guayas river basin district. Adapted from (Madrid-López and Giampietro, 2015).

We use SWAT parameters as proxies for the estimation of five different water metabolism semantic categories, ${ }^{2}$ as presented in Madrid-Lopez and Giampietro (2014) (Table 1):

- Ecosystem water funds refer to the natural runoff $\left(R_{\text {nat }}\right)$ and soil water storage $\left(S W S_{\text {ecosystems }}\right)$ patterns. $R_{\text {nat }}$ and $S W S_{\text {ecosystems }}$ are calculated following Salmoral et al. (2017).

- Ecosystem water flows refers to the water demand from terrestrial and aquatic ecosystems for their proper functioning.

\footnotetext{
${ }^{2}$ More details in Supplemental Material
}

- Societal available water $(S A W)$ is the amount of water that can be used by society taking into account constraints of ecosystem water demands and available infrastructure.

- Gross water appropriation (GWA) includes the consumptive (i.e., evaporation, transpiration, integration into a product, or release into a different drainage basin or the sea) and non-consumptive (i.e., water used for cooling or polluted water) water used for human activities.

- Net water use (NWU) considers only consumptive water that has actually been used (excluding losses).

We perform a monthly step analysis during the period 2004-2013 for each subbasin generated by SWAT. The outputs are later summa- 
Table 1

Water metabolism semantic categories adapted from Madrid-Lopez and Giampietro (2014) and the proxies estimated with SWAT.

\begin{tabular}{|c|c|c|c|c|}
\hline $\begin{array}{l}\text { Water } \\
\text { function }\end{array}$ & \multicolumn{2}{|c|}{$\begin{array}{l}\text { Water metabolism } \\
\text { category }\end{array}$} & Water types & SWAT parameter \\
\hline \multirow[t]{3}{*}{ Fund } & \multirow{3}{*}{\multicolumn{2}{|c|}{ Ecosystem water }} & $\begin{array}{l}\text { Natural runoff } \\
\left(R_{\text {nat }}\right)\end{array}$ & $\begin{array}{l}\text { Streamflow without } \\
\text { human abstractions }\end{array}$ \\
\hline & & & $\begin{array}{l}\text { Soil water storage } \\
\left(S W S_{\text {ecosystems }}\right)\end{array}$ & $\begin{array}{l}\text { At annual step: } \\
\text { evapotranspiration } \\
\text { without irrigation } \\
\text { practices }\end{array}$ \\
\hline & & & & $\begin{array}{l}\text { At monthly step: sum of } \\
\text { the soil moisture and } \\
\text { effective precipitation at } \\
\text { the beginning of each } \\
\text { month }\end{array}$ \\
\hline \multirow[t]{2}{*}{ Flow } & \multirow{2}{*}{\multicolumn{2}{|c|}{ Ecosystem water }} & $\begin{array}{l}\text { Environmental flow } \\
\text { requirements } \\
(E F R)\end{array}$ & $\begin{array}{l}\text { River flow left to the } \\
\text { aquatic ecosystems }\end{array}$ \\
\hline & & & $\begin{array}{l}\text { Evapotranspiration } \\
\text { from the } \\
\text { environment }\end{array}$ & $\begin{array}{l}\text { Evapotranspiration from } \\
\text { terrestrial ecosystems }\end{array}$ \\
\hline \multirow[t]{3}{*}{ Fund } & \multirow[t]{3}{*}{$\begin{array}{l}\text { Societal } \\
\text { available } \\
\text { water } \\
(S A W)\end{array}$} & \multirow[t]{2}{*}{$\begin{array}{c}\text { Blue water } \\
\left(S A W_{\text {blue }}\right)\end{array}$} & $\begin{array}{l}\text { Available } \\
\text { streamflow }\left(R_{\text {nat }}-\right. \\
E F R)\end{array}$ & $\begin{array}{l}\text { Water yield without } \\
\text { human abstractions } \\
\text { minus environmental } \\
\text { flow requirements. It } \\
\text { only considers surface } \\
\text { water connected to } \\
\text { active shallow aquifer. }\end{array}$ \\
\hline & & & Reservoirs $\left(S T_{\text {res }}\right)$ & $\begin{array}{l}\text { Water stored in } \\
\text { reservoirs }\end{array}$ \\
\hline & & $\begin{array}{l}\text { Green water } \\
\left(S A W_{\text {green }}\right)\end{array}$ & $\begin{array}{l}\text { Soil water storage } \\
\text { for human } \\
\text { purposes } \\
\left(S W S_{\text {human }}\right)\end{array}$ & $\begin{array}{l}\text { At annual step: } \\
\text { evapotranspiration } \\
\text { without irrigation } \\
\text { practices for croplands } \\
\text { and pasturelands } \\
\text { At monthly step: sum of } \\
\text { the soil moisture and } \\
\text { effective precipitation at } \\
\text { the beginning of each } \\
\text { month for croplands and } \\
\text { pasturelands }\end{array}$ \\
\hline \multirow[t]{10}{*}{ Flow } & \multirow{5}{*}{\multicolumn{2}{|c|}{$\begin{array}{l}\text { Gross water } \\
\text { appropriation }(G W A)\end{array}$}} & $\begin{array}{l}\text { Households water } \\
\text { abstractions }\end{array}$ & Gross water withdrawn \\
\hline & & & $\begin{array}{l}\text { Industry water } \\
\text { abstractions }\end{array}$ & Gross water withdrawn \\
\hline & & & $\begin{array}{l}\text { Surface water } \\
\text { evaporation }\end{array}$ & $\begin{array}{l}\text { Evaporation losses from } \\
\text { surface water bodies }\end{array}$ \\
\hline & & & $\begin{array}{l}\text { Agricultural } \\
\text { irrigation water } \\
\text { abstractions }^{\mathrm{a}}\end{array}$ & $\begin{array}{l}\text { Gross irrigation from } \\
\text { surface water and } \\
\text { reservoir sources }\end{array}$ \\
\hline & & & $\begin{array}{l}\text { Agricultural soil } \\
\text { water flows }\end{array}$ & $\begin{array}{l}\text { Evapotranspiration in } \\
\text { agricultural areas, } \\
\text { excluding irrigation }\end{array}$ \\
\hline & \multirow[t]{5}{*}{$\begin{array}{l}\text { Net water } \\
\text { use } \\
(N W U)\end{array}$} & \multirow[t]{4}{*}{$\begin{array}{l}\text { Blue water } \\
\left(N W U_{b l u e}\right)\end{array}$} & $\begin{array}{l}\text { Households water } \\
\text { consumption }\end{array}$ & Net water withdrawn \\
\hline & & & $\begin{array}{l}\text { Industry water } \\
\text { consumption }\end{array}$ & Net water withdrawn \\
\hline & & & $\begin{array}{l}\text { Surface water } \\
\text { evaporation }\end{array}$ & $\begin{array}{l}\text { Evaporation losses from } \\
\text { surface water bodies }\end{array}$ \\
\hline & & & $\begin{array}{l}\text { Agricultural } \\
\text { irrigation water } \\
\text { consumption }^{\mathrm{a}, \mathrm{b}}\end{array}$ & $\begin{array}{l}\text { Net irrigation from } \\
\text { surface water and } \\
\text { reservoir sources }\end{array}$ \\
\hline & & $\begin{array}{r}\text { Green water } \\
\left(N W U_{\text {green }}\right)\end{array}$ & $\begin{array}{l}\text { Agricultural soil } \\
\text { water flows }^{\text {b }}\end{array}$ & $\begin{array}{l}\text { Evapotranspiration in } \\
\text { agricultural areas, } \\
\text { excluding irrigation } \\
\text { source }\end{array}$ \\
\hline
\end{tabular}

\footnotetext{
It does not consider losses during water distribution.

${ }^{\text {b }}$ Part of the water consumed for local agricultural production will be exported in the form of virtual water.
}

rized by the total river basin district and at yearly steps. The detailed information required to run SWAT, design the model and evaluate its performance is included in the Supplemental Material.

\subsection{Evaluating food and water security links and water productivities}

The evaluation of food and water security has been assessed with three different approaches ${ }^{3}$ :

- Water security can be framed focusing on quantity and availability of water (Rodrigues et al., 2014), which in the end is also related to food security to meet agricultural needs (Cook and Bakker, 2012). Blue flow/fund shows the water stress by subbasin $s$ and month $m$ and is quantified as a ratio of water consumed to water available:

$$
\text { blue flow } / \text { fund }_{s, m}=\frac{N W U_{\text {blue }}}{S A W_{\text {blue }}}
$$

Where, $N W U_{\text {blue }}$ : net water use in streamflow (volume time ${ }^{-1}$ ); $S A W_{\text {blue }}$ : societal available water in streamflow (volume time ${ }^{-1}$ ) Similarly, green flow/fund:

$$
\text { green flow } / \text { fund }_{s, m}=\frac{N W U_{\text {green }}}{S W S}
$$

Where, $N W U_{\text {green }}$ : agricultural soil water consumption from rainfall source (volume time ${ }^{-1}$ ); $S W S$ : soil water storage (volume time ${ }^{-1}$ ) $N W U_{\text {blue }}$ and $S A W_{\text {blue }}$ are calculated as the sum of the flows and funds for all subbasins upstream of the subbasin under study. In contrast, $N W U_{\text {green }}$ and $S W S$ only refer per subbasin.

- Blue water security is also evaluated with a weighted population under poverty by the volume of unavailable water per unit of drainage area (Poverty water unsecure ${ }_{s, m}$, in inhabitants $\mathrm{m}^{3} / \mathrm{m}^{2}$ ), when net blue water use exceeds societal available water:

$$
\begin{aligned}
& \text { Poverty water unsecure }_{s, m} \\
& =\frac{\text { Population }_{\text {poverty }} \times\left(N W U_{\text {blue }}-S A W_{\text {blue }}\right)}{\text { drainage area }} \text { if } N W U_{\text {blue }}>S A l
\end{aligned}
$$

Where, population poverty: population under poverty for each drainage area; drainage area: sum of the total upstream subbasin area for each under study $\left(\mathrm{m}^{2}\right)$

In the GRBD a total 3,681,472 inhabitants are considered to be living in poverty (INEC, 2011; CISPDR, 2015).

- Crop water productivity $\left(C W P\right.$ in $\left.\mathrm{kg} / \mathrm{m}^{3}\right)$ and crop water nutrition $(C W N, \mathrm{kcal} / \mathrm{L})$ assess the level of food production in relation to water consumption, including both blue and green water. These are calculated at subbasin level and annual resolution in dry matter content for croplands and pasture. Crops production is first converted into the main food product applying extraction coefficients and later to kcal.

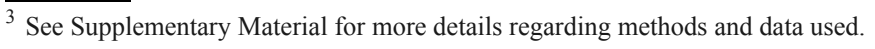




\subsection{Scenarios towards water and food security aims}

Four scenarios evaluate the implications on local water resources and food provision by 2035 due to changes on water infrastructure and agricultural land uses (Table A6). ${ }^{4}$

\subsection{1. "Irrigation": Development of new water infrastructure under current crop patterns}

This scenario exclusively shows the planned expansion of irrigated areas (from 413,420 to $814,900 \mathrm{ha}$ ) and reservoir storage capacity (from 8625 to $12,332 \mathrm{hm}^{3}$ ) according to the GRBD Hydraulic Plan. The crop distribution area is the same as in the baseline scenario (Fig. 1).

In the following scenarios, the irrigated areas, storage capacity and water transfers are kept the same as in Irrigation. The only condition that changes is crop distributions.

\subsection{2. "Exports": Crop pattern changes supporting international exports}

Crop pattern changes are justified by the enthusiasm for international exports. Between 2013 and 2035 coffee, cocoa and palm oil areas are annually increased by $1 \%$ and the reforested areas by $2 \%$, according to the existing agricultural and reforestation programs. To meet this expansion, pasture land and natural herbaceous vegetation are reduced by 170,283 and 2090 ha, respectively.

\subsection{3. "Sovereignty": Crop pattern changes towards food sovereignty aims}

This scenario promotes agricultural production and consumption within the country. Sugar cane, soya and yellow corn are selected towards food sovereignty aims, since these are the main products that Ecuador currently imports. They are increased with an annual growth rate of $1.6 \%, 2.2 \%$ and $2.2 \%$, respectively. To allow this crop pattern change, a total area of 171,470 ha is reduced, including mainly pasture land, followed by natural herbaceous vegetation, white corn and bush areas.

\subsection{4. "Mix": Promotion of both international exports and food sovereignty aims}

The last scenario assesses the overall changes from Scenarios 2 and 3 , supported by the idea that a mix from previous scenarios might be the most plausible future option.

\section{Results}

\subsection{The water metabolism of the GRBD}

The annual median ecosystem blue water fund during the study pe$\operatorname{riod}\left(31,793 \mathrm{hm}^{3}\right.$ - i.e., $\left.714 \mathrm{~mm}\right)$ is slightly larger than the green water fund $\left(30,553 \mathrm{hm}^{3}-\right.$ i.e., $\left.686 \mathrm{~mm}\right)$. At subbasin level both streamflow (between 90 and $1960 \mathrm{~mm}$ ) and soil water (between 60 and $1030 \mathrm{~mm}$ ) funds differ spatially (Fig. A2). At the societal level, streamflow availability is reduced to meet environmental flow requirements, but the presence of reservoirs provide an additional median annual volume of $5375 \mathrm{hm}^{3}$. The agricultural character of the river basin district is shown by the dominance of freshwater water flows for agricultural production. Agricultural production allocates $75 \%$ and $64 \%$ of the blue and green net water use, respectively. The

\footnotetext{
${ }^{4}$ More details about data and methods applied are available in the Supplemental Material
}

GRBD is water self-sufficient in food trade because it exports in the international market more virtual water $\left(4345 \mathrm{hm}^{3}\right)$ than it imports $\left(1064 \mathrm{hm}^{3}\right)$. However, the exports depend on a greater extent to blue water, which comprises $30 \%$ of virtual water exports, whereas blue virtual water imports only make up $10 \%$ (Fig. 3 ).

The south-east of the basin is where the largest annual net blue water use (i.e., $N W U_{\text {blue }}$ ) occurs $(>200 \mathrm{~mm})$. In those subbasins irrigation comprises more than $98 \%$ of the $N W U_{\text {blue }}$, except for subbasin 31 where $50 \%$ of the water consumption refers to urban demand to supply Guayas city. Subbasins with the greatest $N W U_{\text {green }}$ (i.e., $>800 \mathrm{~mm}$ ) are located in the centre and north (Fig. 4). The values of these green water flows are shaped by existing land use distribution, and also by climatic conditions and capacity of soils to store water.

\subsection{Water stress and population under poverty}

At subbasin and monthly steps, some regions appear as blue water unsecure due to water scarce conditions. $N W U_{\text {blue }}$ exceeds the available blue water for human purposes (i.e., $S A W_{\text {blue }}$ ) in the south east, central and upper parts (Fig. 5). Blue flow/fund takes values $>1$ upstream Angas, Cañar, Macul dam and Quevedo monitoring stations. There are also cases (i.e., Babahoyo, Chimbo and Macul dam stations) when even the monthly $S A W_{\text {blue }}$ shows negative values (Fig. 5), which means that available streamflow and water stored in reservoirs cannot cover the environmental flow requirements (Table A7). In contrast, Daule Peripa and Vince reservoirs, located at the north-west and central part, allow water savings during the wet period to maintain water demand downstream (i.e., Daule II and Vince stations).

Green flow/fund has the smallest values (i.e., <0.6) for all subbasins between February and April, which coincides with the rainy season. October and November, is when green flow/fund $>0.6$ occurs mostly for subbasins located in the centre of the GRBD, whereas in July, it occurs for subbasins located in the northwest (Fig. A4). This is probably explained by different precipitation distribution in the study area.

Poverty water unsecure (inhabitants $\mathrm{m}^{3} / \mathrm{m}^{2}$ ) weights the total population living in poverty by the volume of unsecure blue water per drainage area. East GRBD is where most times $N W U_{\text {blue }}$ exceeds the existing fund for human purposes (grey subbasins in Fig. 6). Poverty water unsecure shows monthly median values larger than 1000 inhabitants $\mathrm{m}^{3} / \mathrm{m}^{2}$ upstream Babahoyo station, Chimbo station and subbasin 38 (Fig. 6). The population under poverty and blue water stress differs greatly from year and month depending on the climatic years (i.e., from zero to a maximum of 1,260,317 inhabitants) (Table A8). Median monthly values of poverty water unsecure ranges from 2057 (February) to 7522 (September) inhabitants $\mathrm{m}^{3} / \mathrm{m}^{2}$, considering all the affected areas. A total population of 1,200,996 inhabitants and $51 \%$ GRBD's area is under monthly blue water stress (unsecure volume of blue water from 39 to $142 \mathrm{hm}^{3}$ ) (Table A9).

\subsection{Food vs water security}

In the GRBD, $28.9 \times 10^{\wedge} 13 \mathrm{kcal}$ (including pastures) are produced as median annual values for the study period, $31 \%$ allocated for crops for exports and the remaining for food sovereignty crops. Regarding blue water, crops for exports account for $53 \%$ of the gross water appropriation, whereas sovereignty crops allocate $47 \%$. For green water, the magnitude of sovereignty crops goes up to $72 \%$ of the total green water consumption (Table 2).

The most efficient areas for food production in terms of water consumption (i.e., greater $C W P$, in $\mathrm{kg} / \mathrm{m}^{3}$ ) are mostly found in the centre and south east, with median values from 0.41 to $2.85 \mathrm{~kg} \mathrm{~m}^{-3}$ 


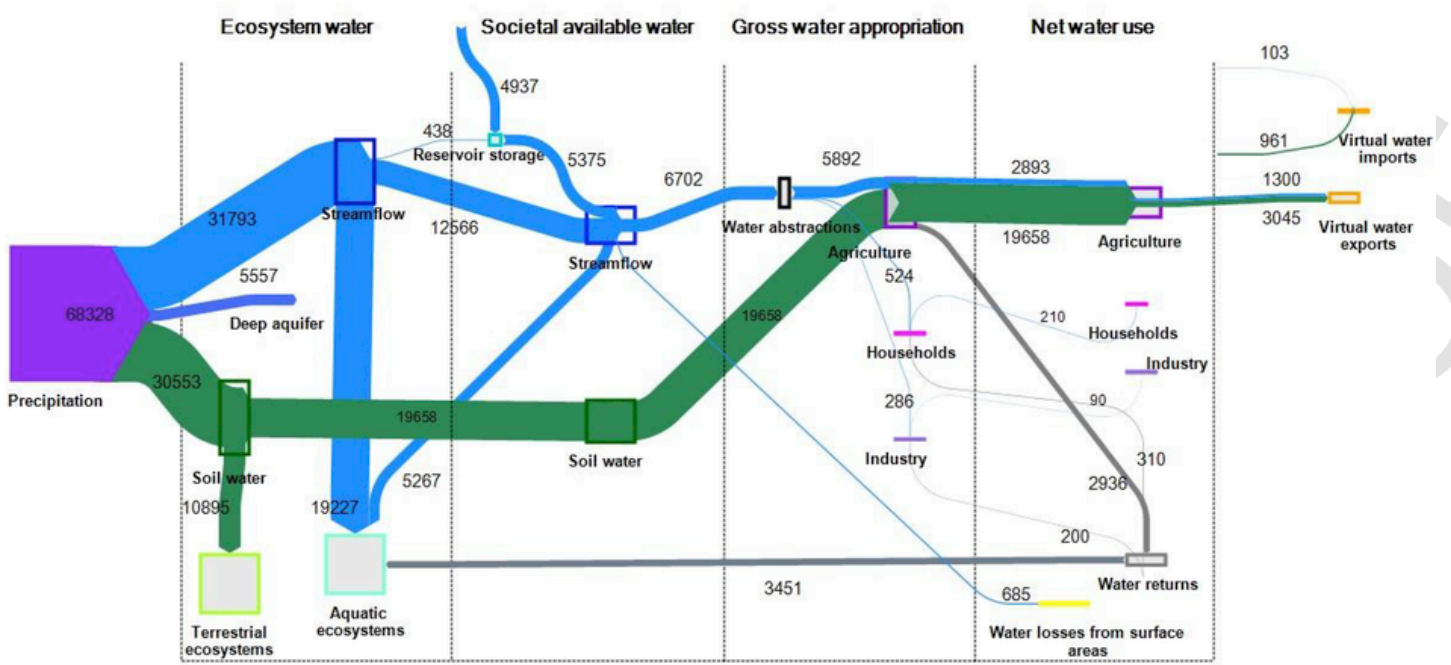

Fig. 3. Links between the water metabolism of ecosystems and society in the GRBD. Annual median values in $\mathrm{hm}^{3}$ for the period $2004-2013$.

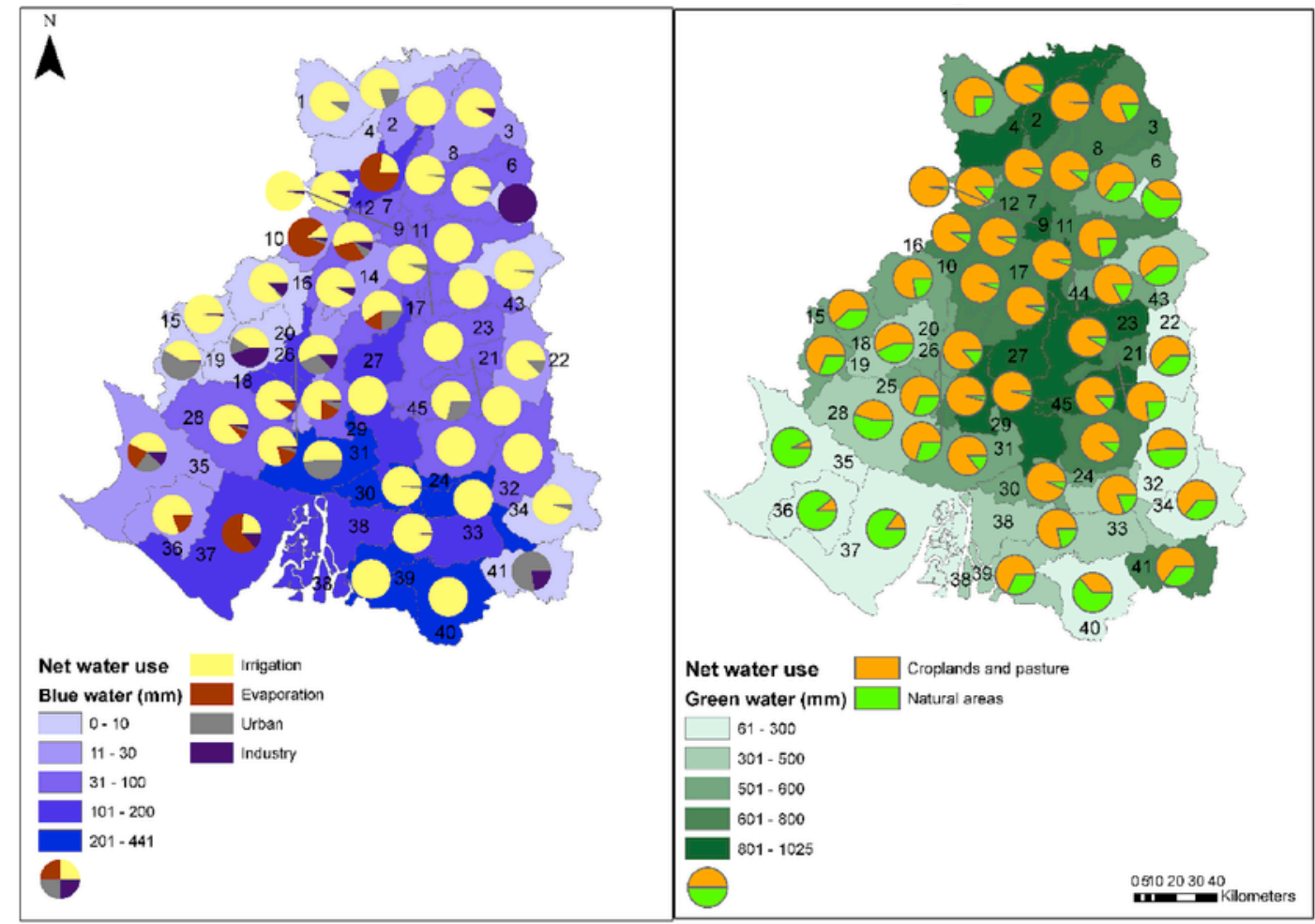

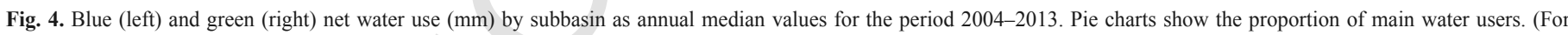
interpretation of the references to colour in this figure legend, the reader is referred to the Web version of this article.)

(Fig. 7a). High pasture yields generate high $C W P$ in some subbasins (e.g., subbasin 18). Larger $C W P$ also takes place in subbasins with a dominant presence of sugar cane and banana (e.g., subbasins 23 and 27). In contrast, subbasins within the Andean region have the lowest $C W P$ with values below $0.1 \mathrm{~kg} \mathrm{~m}^{-3}$ (Fig. 7a).

In terms of nutritional value, as expected, those subbasins with irrigation can produce larger quantities of kcal too (i.e. greater $C W N$, in $\mathrm{kcal} / \mathrm{L})$. $C W N$ shows a similar geographic distribution as $C W P$. However, some differences are found due to the existing crops patterns per subbasin and caloric content of the food product they provide
(Fig. 7b). For instance, subbasins 42 and 43 has a median of 0.45 and $0.34 \mathrm{~kg} \mathrm{~m}^{-3} C W P$, respectively, but the median $C W N$ is 8.3 and $6.3 \mathrm{kcal} / \mathrm{L}$. This is due to the existence of sugarcane in $10 \%$ of each subbasin area, which shows both a high crop yield and caloric content (387 kcal/100 g).

\subsection{Water and food security changes under 2035 scenarios}

In the proposed scenarios, annual median values of societal available blue water $\left(S A W_{\text {blue }}\right)$ (i.e., natural runoff - environmental flow 


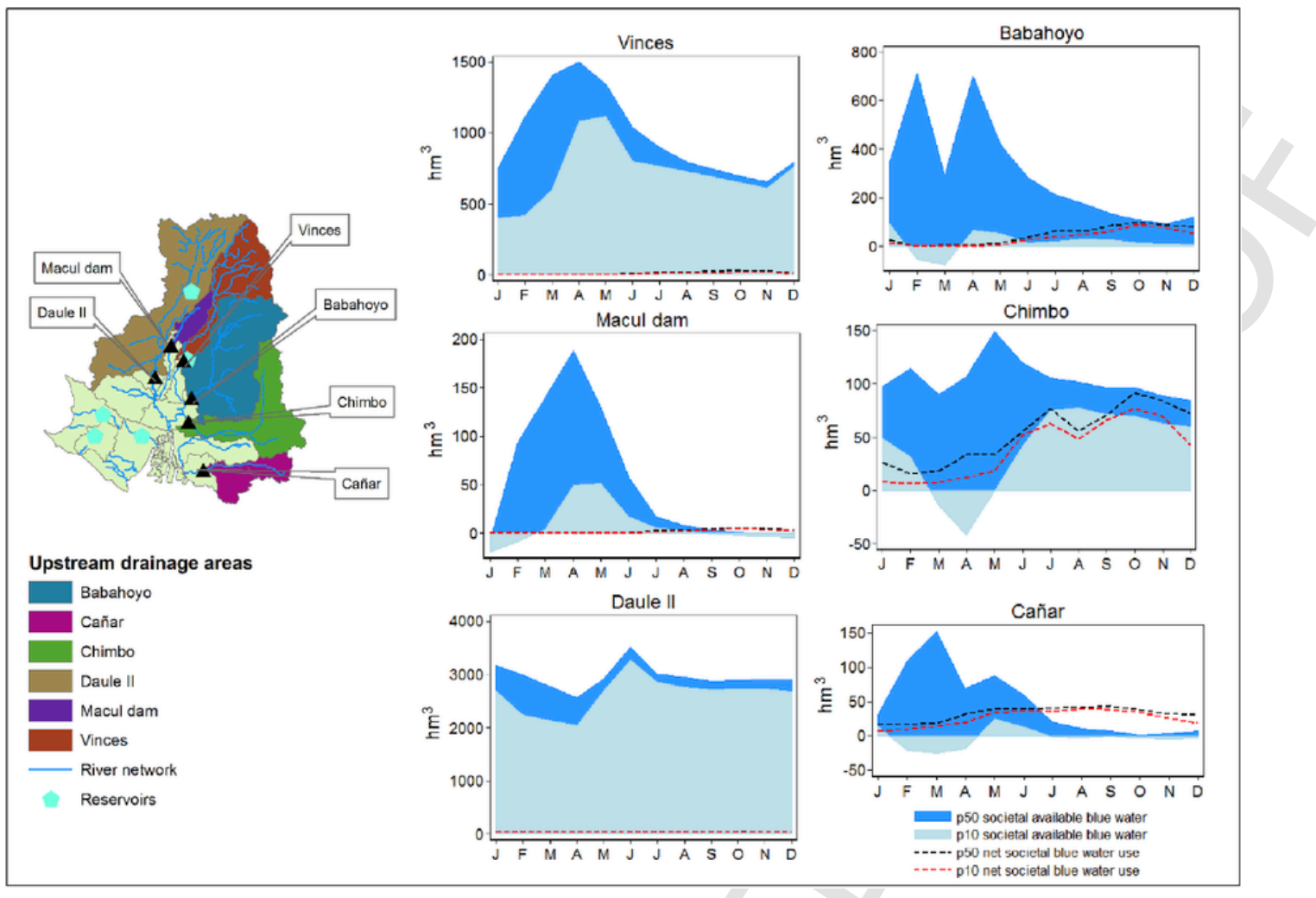

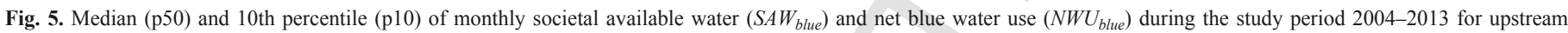
drainage areas. (For interpretation of the references to colour in this figure legend, the reader is referred to the Web version of this article.)

requirements + reservoir storage) decreased in comparison to Baseline (from 17,940 in Baseline to $16,130 \mathrm{hm}^{3}$ in Mix). Available streamflow decreased from 12,565 in Baseline to $8460 \mathrm{hm}^{3}$ in Mix, but this decrease is offset by providing water from reservoirs. Gross (net) irrigation raises from 5890 (2895) in Baseline to $10,165 \mathrm{hm}^{3}(6135)$ in Mix. In contrast, agricultural green water consumption declines from 19,660 (Baseline) to $18,505 \mathrm{hm}^{3}$ (Exports) (Table A10).

The scenarios show a decrease in $N W U_{\text {blue }}$ in relation to existing $S A W_{\text {blue }}$, as additional reservoirs can mitigate water stress that was occurring in some regions in Baseline. Blue flow/fund is reduced from Baseline to proposed scenarios into values $<1$ in Macul dam, Chimbo, Babahoyo and Cañar (Fig. 8 for median values and Fig. A5 for 90th percentile). Moreover, with the proposed scenarios, no negative $S A W_{\text {blue }}$ takes place as in baseline scenario (Table A7), meaning that available streamflow and water stored in reservoirs can meet the required environmental flow requirements, as long as adequate management of water release from reservoirs is carried out. Nevertheless, upstream Chimbo station still faces water security issues due to water stress in the proposed scenarios. About $95 \mathrm{hm}^{3}$ reservoir capacity have been added in Chimbo's upstream subbasins, but blue water stress has worsened due to increased irrigation.

Considering the entire GRBD, the largest increase on agricultural production occurs in the Irrigation scenario, which is related to the weight that pasture production provides to the total agricultural production, also reflected in the greatest $C W P$ in the Irrigation scenario $\left(0.55 \mathrm{~kg} \mathrm{~m}^{-3}\right)$. However, the greatest amount of kcal is produced in the Sovereignty and Mix scenarios, mainly due to sugar cane, soya and corn. Both scenarios also show the greatest $C W N(1.47 \mathrm{kcal} / \mathrm{L}$ in $S o v-$ ereignty and $1.48 \mathrm{kcal} / \mathrm{L}$ in Mix) (Table A10). At the subbasin level, $C W P$ increases in 31 out of 45 subbasins in Irrigation, whereas in the Exports, scenario only 23 subbasins increment their CWP. Sov- ereignty shows the largest number of subbasins increasing their $C W P$ with a total of 36 subbasins out of 45 , related to the change of crop patterns. In contrast, all subbasins increase their $C W N$. The largest changes take place in Sovereignty and Mix, where 11 out of 45 subbasins increase the annual median $C W N$ by more than $2 \mathrm{kcal} / \mathrm{L}$ (Fig. 9).

\section{Discussion}

\subsection{The novelty of water metabolism for assessing water and food security}

Within hydrological research, there are many evaluations on the different components of the water cycle (e.g., runoff generation, groundwater recharge, evapotranspiration) and a vast experience in hydrological planning on the allocation of flowing blue water resources. However, approaches that are able to consider in more detail the current links between natural and societal water systems are needed, like the one addressed here. A multi-level visualization to work towards ILWRM approaches is relevant to understand the overall view (from the natural system to final users) of water allocation, considering both streamflow and rainfall stored in the soil. In the GRBD, within the ecosystem water budget, annual streamflow water availability exceeds 1.04 times soil water, which coincides with the 1.05 ratio that has been found in similar subtropical humid conditions (Chen et al., 2016). In contrast, under drier climate conditions, such as in the Mediterranean climate, this value can drop to 0.3 (Salmoral et al., 2017), with this ratio depending on the capacity of soils to store rainfall.

In the GRBD and period under study, green water (as median annual value) comprises the largest water consumption with $29 \%$ of the 

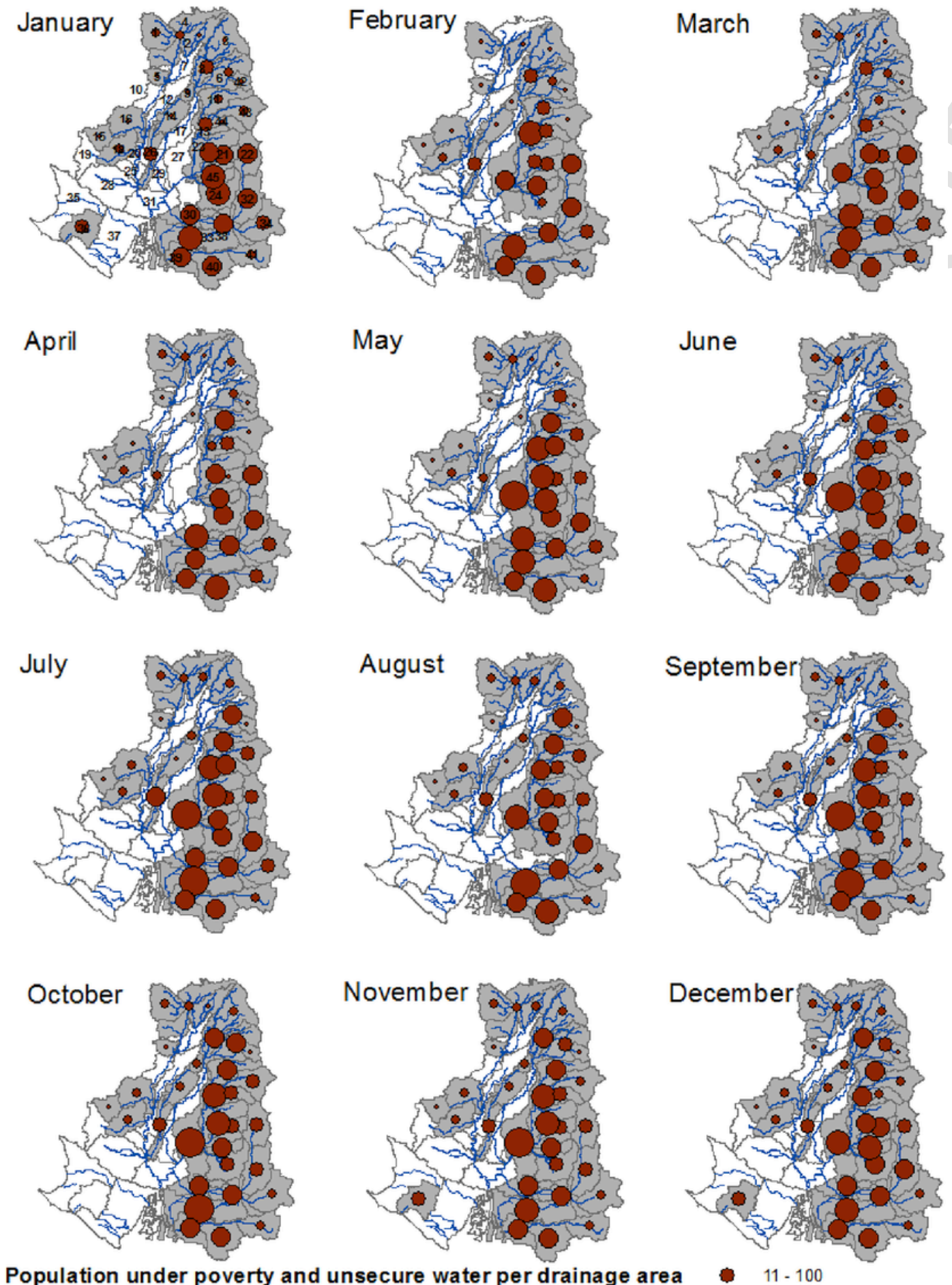

Population under poverty and unsecure water per drainage area (inhabitants $\mathrm{m} 3$ )/m2
- $11-100$
$101-1,000$
$1,001-3,000$
$3,001-4,170$

- $\quad 2-10$

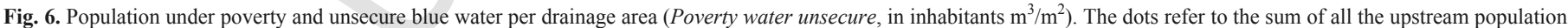
unavailable water and area. (For interpretation of the references to colour in this figure legend, the reader is referred to the Web version of this article.)

annual precipitation, in comparison to the net blue water with $6 \%$ annual precipitation. The high rainfall and runoff generation in some regions of the GRBD accounts for green water consumption values be- low the $55-60 \%$ global estimations, whereas the presence of irrigation makes blue water consumption above the $1 \%$ global average of precipitation (Vanham, 2015). Agriculture is the largest water con- 
Table 2

Summary of median annual values of water metabolism variables by crops for exports or food sovereignty purposes.

\begin{tabular}{|c|c|c|c|c|c|c|c|c|c|}
\hline & & Area (ha) & $\begin{array}{l}\text { Yield in dry } \\
\text { weight (t/ha) }\end{array}$ & $\begin{array}{l}\text { Kcal } \\
\text { supplied }\end{array}$ & $\begin{array}{l}\text { Gross blue water } \\
\text { flow }\left(\mathrm{hm}^{3}\right)\end{array}$ & $\begin{array}{l}\text { Net blue water } \\
\text { flow }\left(\mathrm{hm}^{3}\right)\end{array}$ & $\begin{array}{l}\text { Green water } \\
\text { flow }\left(\mathrm{hm}^{3}\right)\end{array}$ & $\begin{array}{l}\text { Crop water } \\
\text { productivity }\left(\mathrm{kg} / \mathrm{m}^{3}\right)\end{array}$ & $\begin{array}{l}\text { Crop water } \\
\text { nutrition }(\mathrm{kcal} / \mathrm{L})\end{array}$ \\
\hline \multirow[t]{5}{*}{ Exports } & Total & 666,470 & 2.7 & $8.90 \mathrm{E}+12$ & 3140 & 1550 & 5400 & 0.26 & 1.28 \\
\hline & Banana & 167,870 & 8.9 & $7.80 \mathrm{E}+12$ & 1960 & 990 & 1370 & 0.63 & 3.31 \\
\hline & Cocoa & 408,250 & 0.3 & $6.30 \mathrm{E}+11$ & 1180 & 560 & 3280 & 0.03 & 0.16 \\
\hline & Coffee & 38,640 & 0.2 & 0 & 0 & 0 & 310 & 0.02 & 0 \\
\hline & Oil palm & 51,710 & 4 & $4.80 \mathrm{E}+11$ & 0 & 0 & 440 & 0.48 & 1.1 \\
\hline \multirow[t]{8}{*}{ Sovereignty } & Total & $2,307,960$ & 3.5 & $2.00 \mathrm{E}+13$ & 2730 & 1340 & 14,100 & 0.52 & 1.3 \\
\hline & $\begin{array}{l}\text { Total (without } \\
\text { pastures) }\end{array}$ & $1,227,870$ & 3.4 & $1.90 \mathrm{E}+13$ & 2430 & 1190 & 6480 & 0.55 & 2.48 \\
\hline & Pasture & $1,080,090$ & 3.6 & $7.60 \mathrm{E}+11$ & 300 & 140 & 7620 & 0.5 & 0.1 \\
\hline & Rice & 370,010 & 3.3 & $5.30 \mathrm{E}+12$ & 1070 & 540 & 2390 & 0.41 & 1.81 \\
\hline & Soy & 52,860 & 1.2 & $1.20 \mathrm{E}+11$ & 20 & 10 & 100 & 0.56 & 1.04 \\
\hline & Sugar cane & 147,270 & 13.8 & $1.30 \mathrm{E}+13$ & 1120 & 530 & 980 & 1.34 & 8.58 \\
\hline & White corn & 262,010 & 0.4 & $5.00 \mathrm{E}+11$ & 90 & 40 & 1620 & 0.07 & 0.3 \\
\hline & Yellow corn & 395,730 & 2 & $5.10 \mathrm{E}+11$ & 120 & 70 & 1390 & 0.54 & 0.35 \\
\hline
\end{tabular}
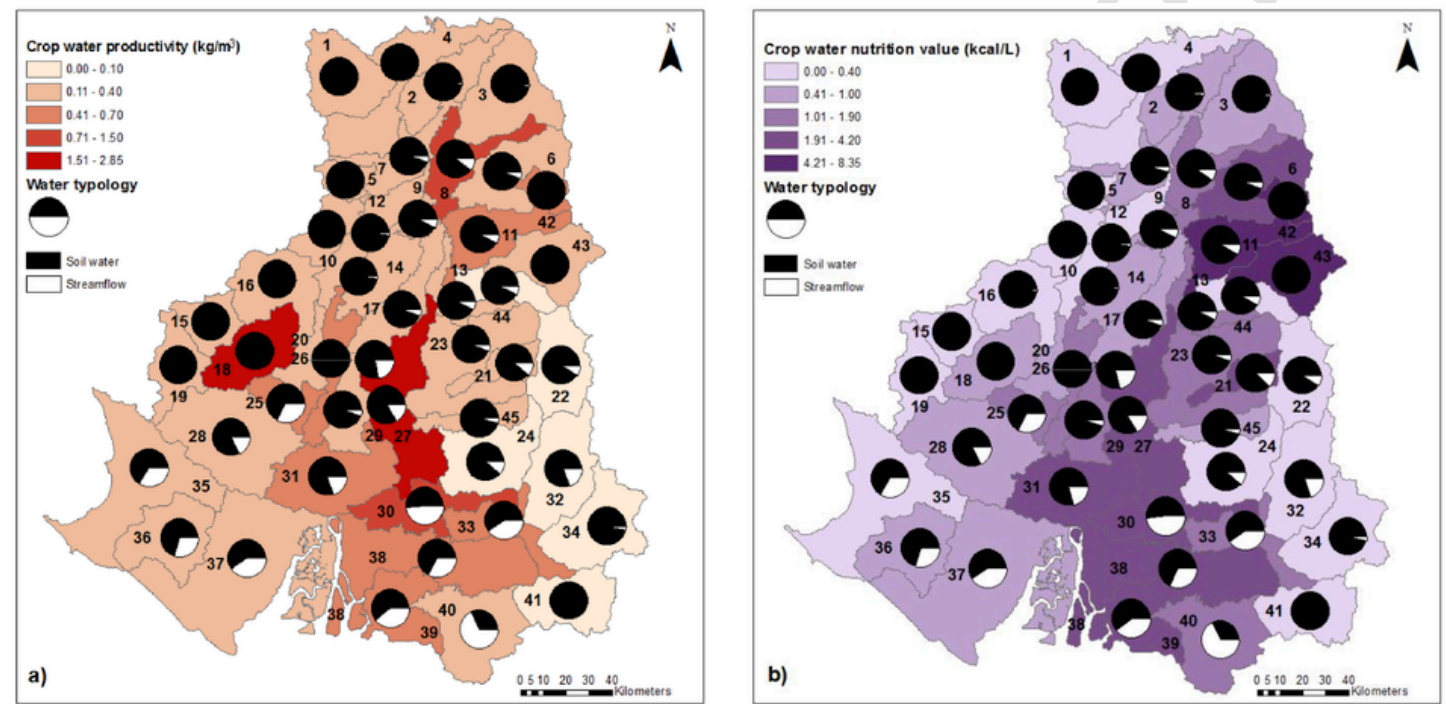

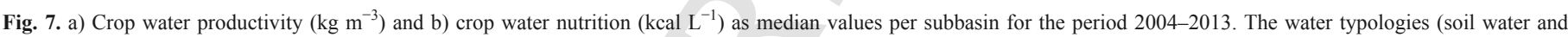
streamflow) are also shown.

suming sector, demanding $64 \%$ and $75 \%$ of the green and net blue water flows, respectively, showing blue water consumption values slightly below the global average of $80-87 \%$ (Hoekstra and Mekonnen, 2012; ibid). The detailed evaluation of blue and green water flows indicates the dependence on climatic, soil and anthropogenic conditions as well as the relevance of assessing both flows in water and food security evaluations (Veettil and Mishra, 2016).

The GRBD can be considered rich in blue water resources, however, these are spatiotemporally unevenly distributed (i.e., annual median values from 90 to $1960 \mathrm{~mm}$ ) making it difficult to meet societal water demand under sustainable boundaries throughout the study area. Our water metabolism approach - with the application of flow/ fund ratios - applies a bottom-up process of defining water boundaries at the watershed level (Rockström et al., 2014). It adds value to existing river basin scale studies (Steffen et al., 2015) due to the detailed spatiotemporal assessment of water impacts which occur at more local levels. Our method also shows the value of identifying those populations not achieving water security as well as accounting upstream blue water available to downstream users, as previous global studies have also done (Green et al., 2015). In the GRBD, the greater number of people living under water unsecure conditions are located in the east of the river basin district. This is the area where the central and regional governments will require to put more efforts - in the future - to meet both water and food security for local livelihoods.

Some authors claim that the key for resolving the water-food dilemma is a focus on having more nutritional value per drop of water consumed (Rockström et al., 2014), which we addressed with the application of crop water productivity indicators (i.e., $C W P$ and $C W N$ ). In the GRBD, the increasing order for the $C W N$ is: coffee $<$ pasture $<$ cocoa $<$ white corn $<$ yellow corn $<$ soy $<$ palm oil $<$ rice $<$ banana $<$ sugar cane, ranging from 0 to $8.6 \mathrm{kcal} / \mathrm{L}$ (Table 2 ). However, what needs to be highlighted is that the largest crop water productivities are found in subbasins that are water scarce and with a large proportion of the population living in poverty. In contrast, the lowest productivities are found in the lower populated Andean region due to the lower yields produced under harsh climatic conditions. Besides the uneven biophysical conditions in the GRBD, differences in crop water productivities would also be related to the types of irrigators and their purpose. The aims of indigenous farmers located in the Andean region are mainly for local markets and self-sufficiency. Whereas, farmers located close to the coast largely produce for national consumption and exports e.g., rice, and banana. The latter are associated with agricultural producers associations that give them 


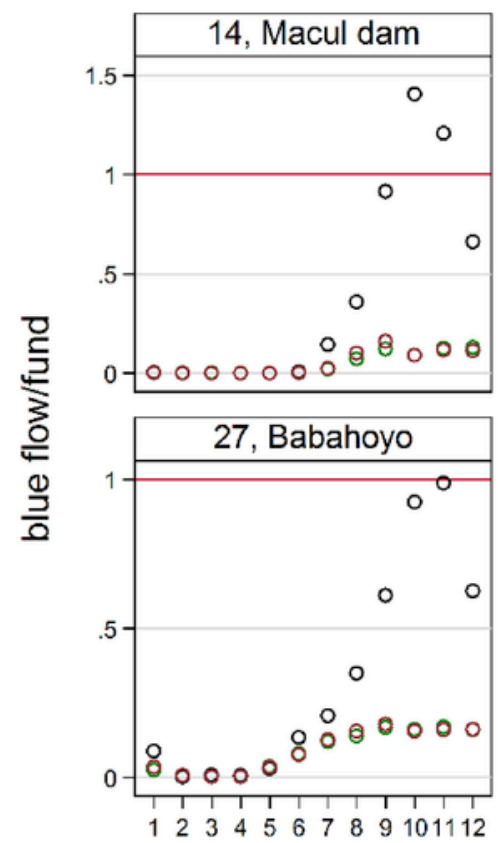

O Baseline
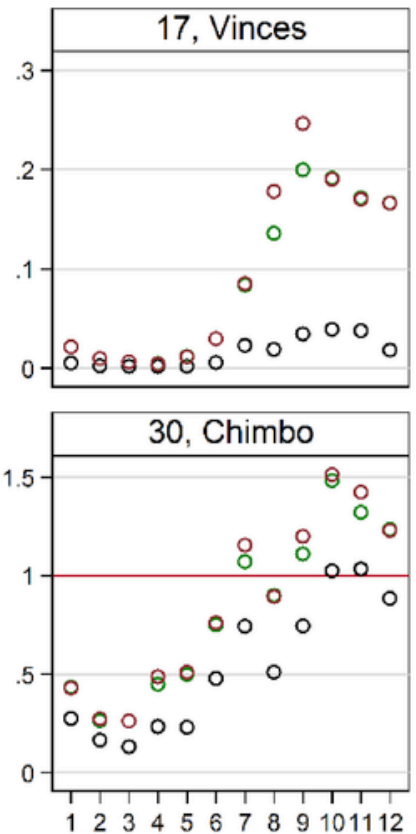

MONTH
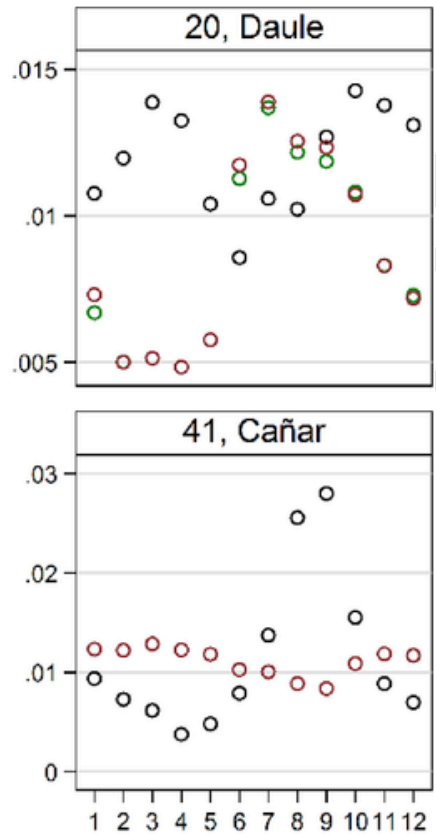

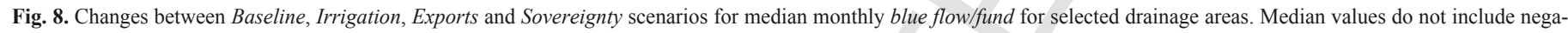

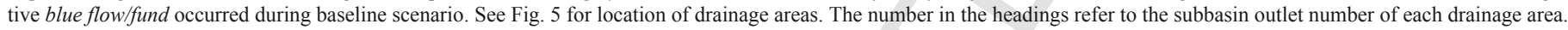
(For interpretation of the references to colour in this figure legend, the reader is referred to the Web version of this article.)

Irrigation

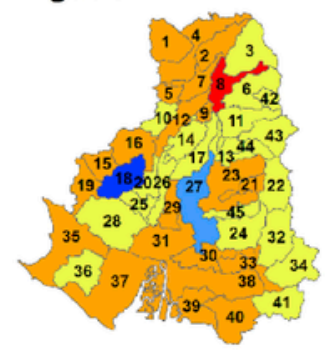

Crop water producitivity $\left(\mathbf{k g} / \mathrm{m}^{3}\right)$

$-0.87--0.20$

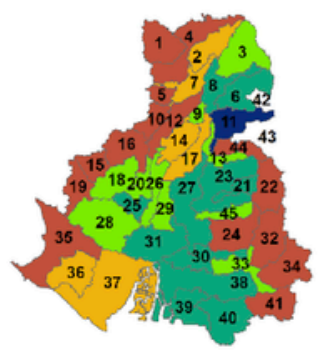

Crop water nutrition (kcal/L)

$0.00-0.50$
Exports

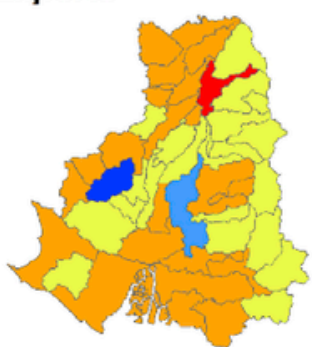

Sovereignty

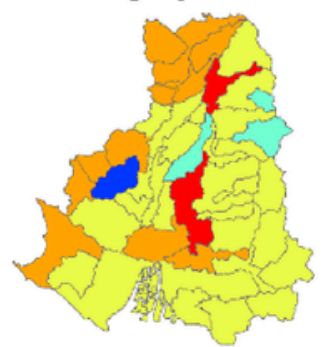

$0.12-0.21$

$0.22-0.40$

\section{Mix}

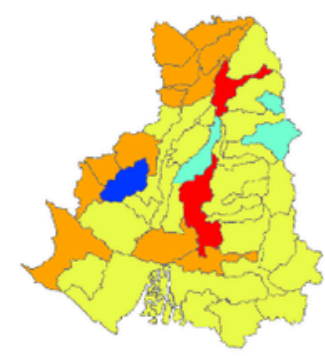

$0.01-0.11$
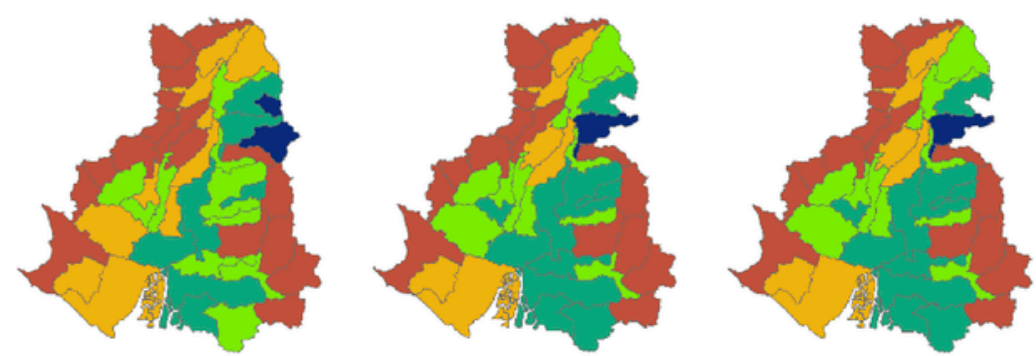

$0.51-1.00$

$2.01-5.00$

$1.01-2.00$

$5.01-11.57$

Fig. 9. Changes on median values for crop water productivity $\left(\mathrm{kg} / \mathrm{m}^{3}\right)$ and crop water nutrition $(\mathrm{kcal} / \mathrm{L})$ between the proposed scenarios and baseline scenario. 
greater access to national and international markets (Gaybor et al., 2008).

\subsection{Understanding agricultural water management findings}

A general concern in irrigation water management is to reduce pressures on local water resources. Consumptive water savings can be achieved when increasing irrigation systems efficiency, as featured in the National Irrigation Plan in Ecuador, which calls for irrigation technology and system efficiency. At field level, blue water withdrawal (i.e., gross water volume) can be reduced with modernized irrigation systems, which helps to redistribute water between sectors (e.g., agriculture, households, ecosystems), but at catchment level consumptive water (i.e., net irrigation) savings do not take place. Even an increase in blue water consumption can occur with higher irrigation systems efficiency, if additional areas are converted into irrigation (Olen et al., 2016) and/or crop patterns change to more water consuming crops (Rodríguez-Díaz et al., 2011) - and with a related added energy demand from 'technified' irrigation systems (ibid; Perez Neira, 2016). '

The study finds that agricultural soil water consumption declines from the baseline to proposed scenarios, because an appropriate irrigation dose has not taken place in relation to crop water requirements. Under auto-irrigation management, SWAT can be set up to a specific irrigation amount when the crop reaches a certain limit of water stress, but this amount must remain consistent, depending on the level of water stress. This leads to: 1) blue water percolation losses, when more irrigation water is applied to what the plant can transpire, and 2) rainfall losses after the irrigation event, because the soil cannot store more water or be used later by the plant. On the field, similar situations can occur. For instance, when land is converted from rainfed to irrigated conditions, crop yield will increase due to a steady application of water throughout the crop development. However, not following an adequate soil water balance and applying an appropriate irrigation dose at a given moment can lead to scarce or excess of irrigation. In the end, appropriate crop irrigation schedules can help farmers to understand crop water requirements and irrigate accordingly. To date in Ecuador, there is still an inadequate water management for irrigation (Espinosa and Rivera, 2016).

\subsection{Implications of Ecuadorian national development on food and water security}

This study demonstrates how water security is driven not only by agro-climatic and geophysical conditions, but also by policy decisions about land use and food security. Food sovereignty in Ecuador is a national issue that has gained centrality in the political debate (Giunta, 2014), but not every nation can be food sovereign because of restrictions imposed by limited arable land, irrigation water and other resources (e.g., energy, fertilizers), particularly in geographically small countries. Thus trade is necessary to overcome ecological, climatic and other location specificities that make up crop division of global production (Agarwal, 2014). In the country, international trade plays a key role on food security, because of scarcity in specific commodities for the Nation's requirements (e.g. wheat mainly supplied from international trade for broilers feed in Ecuador). In the GRBD, we see that the region can be water self-sufficient for agricultural production and related food trade. The GRBD exports more virtual water than imports, although exports embed a larger proportion of blue water resources than imports (i.e., $30 \%$ blue water in exports against $10 \%$ blue water in imports). Nevertheless, the role of primary products exports in the national economy is shown with their signifi- cant share of the Ecuadorian GDP; 24\% in 2013 (Latorre et al., 2015), particularly relevant in the production of cocoa, bananas and coffee (Burnett and Murphy, 2014).

In Ecuador future irrigation plans will support both local food supply and international exports. Scenarios designed in this study can guide and complement future agricultural and water management decisions, towards achieving water and food security. Currently in the GRBD, about 28.7 million kcal are produced, as annual median values for the study period. In our scenarios, total kcal production is increased with the inclusion of new irrigated areas. Nevertheless, the scenarios with the largest total kcal production are Sovereignty and Mix, where more kcal for local consumption also take place. In both scenarios, the area of crops for exports (e.g., banana) and pasture reduces, whereas the area of crops that contribute to local consumption (e.g., yellow corn, sugar cane and soya) increases. Another scenario that could increase total food provision in Ecuador is one offered by Knoke et al. (2013). They propose shrinking existing pasture areas in Ecuador to facilitate an increase in cropland area, while total pasture area could still increase through the re-cultivation of abandoned grazing lands.

The planned state driven development of new irrigated areas and crop patterns will influence distribution of available water resources, as illustrated in the scenarios. $S A W_{\text {blue }}$ in the proposed scenarios decreases in comparison to the baseline, which is partially offset by a greater reservoir management capacity during dry seasons. The planned reservoirs development will help to alleviate water scarce conditions, as long as all reservoirs can be build (and properly) managed, and their construction not be constrained by an unstable national economy. However, additional reservoir development and irrigated areas do not mean that all farmers will have access to land and water. Development of additional reservoirs is managed by the state, but canalization from new infrastructures to final users has not been considered and there is no a plan to date of how these new infrastructures will reach the final end users. There is a risk that development of new irrigated areas might put the country in a similar situation to that during $80-90$ 's, when public irrigation systems were created, but only a small part of the population, with better economic and social position, could get access to it (personal communication, 2015).

\section{Conclusions}

Achieving food security is part of the Ecuadorian political debate and influences decisions around land use and water management. This study provides a detailed spatiotemporal assessment of freshwater resources, and related water security indicators for agricultural production. The importance of catchment approaches is highlighted for balancing human and nature water requirements, and how feasibility of agricultural development needs to address impacts on local water security. Agricultural production allocates the largest freshwater share with $75 \%$ and $64 \%$ of net blue and green water flows, respectively, and the GRBD can be considered as water self-sufficient in food trade due to the positive virtual water exports $\left(4345 \mathrm{hm}^{3}\right)$ and imports $\left(1064 \mathrm{hm}^{3}\right)$ balance. Nevertheless, a total population of 1,200,996 inhabitants and 51\% GRBD's area is under blue water stress, and the study finds water security as a challenge due to the combination of scarce water conditions and population under poverty in the south east and central part of the GRBD. It is in this part of the river basin district, where at the same time, the greatest annual crop water productivity $\left(0.41-2.85 \mathrm{~kg} \mathrm{~m}^{-3}\right)$ and crop water nutrition $(1.9-8.35 \mathrm{kcal} /$ L) are found. The study also provides a first step towards creating agricultural scenarios in Ecuador for water and food provisioning and can aid in meeting the country's water and food security 
goals, providing alternatives that lessen the impacts for land and water use. The scenarios reveal that food provision, towards local food consumption or exports market-oriented, can be increased and ecosystem water demand still be met, with the exception of the east of the GRBD.

Future research could build on our study and further consider other drivers that will affect both water and food security, including demographic changes, droughts (Vicente-Serrano et al., 2016), flooding events (Hallegatte et al., 2013), and existing climatic trends (Morán-Tejeda et al., 2015). Moreover, this research could be extended to perform water-for-energy assessments with the consideration of hydropower development in Ecuador. A comparison of the seasonal effects of water-for-food on hydropower production versus the effects of reservoir management on food production could allow this study to provide additional insights to policy makers regarding their proposed national development strategies, including the recent projects on multi-purpose reservoirs. Finally, the flexibility of the methodology adopted in this study may be applicable to a worldwide scale with an integration of the water metabolism approach to global hydrological and crop growth models. Insights from the study can extend beyond academia to practitioners and policymakers in water and land management beyond our case study. Ultimately, the provided alternatives to promote integrated land and water management in Ecuador can aid towards meeting the country's future water and food security needs.

\section{Acknowledgements}

Funding for this work was provided by CEPROEC (Centro de Prospectiva Estratégica) (CUP 00101819) at Instituto de Altos Estudios Nacionales in Ecuador funded by the National Secretariat of Planning (SENPLADES). Kaysara Khatun's contribution was carried out with funding from the PROMOTEO project of the Secretariat of Higher Education, Science, Technology and Innovations of Ecuador (SENESCYT). Cristina Madrid Acknowledges the support of the 7th FP Marie Curie International Outgoing Fellowship IANEX (contract 623593). We would like to thank the support to the Ecuadorian institutions MAG, SENAGUA, INAHMI and IEE regarding data access and personal communications. The authors are also grateful for the comments and recommendations of four anonymous reviewers, which helped improve the quality of the manuscript.

\section{Appendix A. Supplementary data}

Supplementary data related to this article can be found at https:// doi.org/10.1016/j.jclepro.2018.07.308.

\section{References}

Agarwal, B., 2014. Food sovereignty, food security and democratic choice: critical contradictions, difficult conciliations. J. Peasant Stud. 1-22 https://doi.org/10. 1080/03066150.2013.876996

Arnold, J.F., Srinivasan, R., Muttiah, R.S., Williams, J.R., 1998. Large area hydrologic modeling and assessment. Part I: model development. J. Am. Water Resour. Assoc. 34, 73-89.

Burnett, K., Murphy, S., 2014. What place for international trade in food sovereignty? J. Peasant Stud. 1-20 https://doi.org/10.1080/03066150.2013.876995.

Cabello, V., Madrid, C., 2014. Water use in arid rural systems and the integration of water and agricultural policies in Europe: the case of Andarax river basin. Environ. Dev. Sustain. 16, 957-975 https://doi.org/10.1007/s10668-014-9535-8.

Chen, K., Yang, S., Zhao, C., Li, Z., Luo, Y., Wang, Z., Liu, X., Guan, Y., Bai, J., Zhou, Q., Yu, X., 2016. Conversion of blue water into green water for improving utilization ratio of water resources in degraded karst areas. Water 8, $569 \mathrm{https} / /$ doi.org/10.3390/w8120569.
CISPDR, 2015. Plan Hidraúlico Regional de la Demarcación Hirográfica Guayas. Memoria y Anexos Changjiang Institute of Survey Planning Design and Research.

CISPDR, 2014. Planificación Hídrica Nacional del Ecuador (2014-2035). Phase II Report Changjiang Institute of Survey Planning Design and Research.

Cook, C., Bakker, K., 2012. Water security: debating an emerging paradigm. Global Environ. Change 22, 94-102 https://doi.org/10.1016/j.gloenvcha.2011.10.011.

Cremers, L., Ooijevaar, M., Boelens, R., 2005. Institutional reform in the Andean irrigation sector: enabling policies for strengthening local rights and water management. Nat. Resour. Forum 29, 37-50 https://doi.org/10.1111/j.1477-8947.2005. 00111.x.

Cumming, G.S., Cumming, D.H.M., Redman, C.L., 2006. Scale mismatches in social-ecological systems: causes, consequences, and solutions. Ecol. Soc. 11, 14

de Loë, R.C., Patterson, J.J., 2017. Rethinking water governance: moving beyond water-centric perspectives in a connected and changing world. Nat. Resour. J. 57, 57-99.

Espinosa, J., Rivera, D., 2016. Variations in water resources availability at the Ecuadorian páramo due to land-use changes. Environ. Earth Sci. 75, 1-15 https://doi.org/ 10.1007/s12665-016-5962-1.

Falconí, F., Ramos-Martin, J., Cango, P., 2017. Caloric unequal exchange in Latin America and the Caribbean. Ecol. Econ. 134, 140-149 https://doi.org/10.1016/j. ecolecon.2017.01.009.

Falkenmark, M., Jägerskog, A., Schneider, K., 2014. Overcoming the land-water disconnect in water-scarce regions: time for IWRM to go contemporary. Int. J. Water Resour. Dev. 1-18 https://doi.org/10.1080/07900627.2014.897157.

FAO, 2017. FAOSTAT. Food and Agriculture Organization [WWW Document]. http: //www.fao.org/faostat/en/Accessed 9 December 2017

Gaybor, A., Ramos, A., Tamayo, C., Isch, E., Arroyo, A., 2008. El despojo del agua y la necesidad de una transfromación urgente. Foro de los recursos hídricos, Quito.

Georgescu-Roegen, N., 1971. The Entropy Law and the Economic Process. Harvard University Press, Cambridge, MA., Cambridge, MA.

Giampietro, M., Mayumi, K., Ramos-Martin, J., 2009. Multi-scale integrated analysis of societal and ecosystem metabolism (MUSIASEM): theoretical concepts and basic rationale. Energy 34, 313-322 https://doi.org/10.1016/j.energy.2008.07.020.

Giunta, I., 2014. Food sovereignty in Ecuador: peasant struggles and the challenge of institutionalization. J. Peasant Stud. 41, 1201-1224 https://doi.org/10.1080/ 03066150.2014 .938057$.

Green, P.A., Vörösmarty, C.J., Harrison, I., Farrell, T., Sáenz, L., Fekete, B.M., 2015 Freshwater ecosystem services supporting humans: pivoting from water crisis to water solutions. Global Environ. Change 34, 108-118 https://doi.org/10.1016/j. gloenvcha.2015.06.007.

Guzmán, P., Batelaan, O., Huysmans, M., Wyseure, G., 2015. Comparative analysis of baseflow characteristics of two Andean catchments, Ecuador. Hydrol. Process. https://doi.org/10.1002/hyp.10422.

Hallegatte, S., Green, C., Nicholls, R.J., Corfee-Morlot, J., 2013. Future flood losses in major coastal cities. Nat. Clim. Change 3, 802-806 https://doi.org/10.1038/ nclimate1979.

Hoekstra, A.Y., Mekonnen, M.M., 2012. The water footprint of humanity. Proc. Natl Acad. Sci. U. S. A. 109, 3232-3237 https://doi.org/10.1073/pnas.1109936109.

Hoogesteger, J., 2013. Social capital in water user organization of the Ecuadorian highlands. Hum. Organ. 72, 347-357 https://doi.org/10.17730/humo.72.4. jv2177g624q35253.

INEC, 2015. Population and Housing Census. National Institute of Statistics and Census [WWW Document] http://www.ecuadorencifras.gob.ec/Accessed 9 July 2015.

INEC, 2011. Censo de Población 2010. Instituto Nacional de Estadística y Censos.

Knoke, T., Calvas, B., Moreno, S.O., Onyekwelu, J.C., Griess, V.C., 2013. Food production and climate protection-What abandoned lands can do to preserve natural forests. Global Environ. Change 23, 1064-1072 https://doi.org/10.1016/j. gloenvcha.2013.07.004.

Latorre, S., Farrell, K.N., Martínez-Alier, J., 2015. The commodification of nature and socio-environmental resistance in Ecuador: an inventory of accumulation by dispossession cases, 1980-2013. Ecol. Econ. 116, 58-69 https://doi.org/10.1016/j. ecolecon.2015.04.016.

Madrid-López, C., Cadillo-Benalcazar, J., Diaz-Maurin, F., Kovacik, Z., Serrano-Tovar, T., Gomiero, T., Giampietro, M., Aspinall, R.J., Ramos-Martin, J., Bukkens, S.G.F., 2014. Punjab state, India. In: Giampietro, M., Aspinall, R.J., Ramos-Martin, J., Bukkens, S.G.F. (Eds.), Resource Accounting for Sustainability: the Nexus between Energy, Food, Water and Land Use, Routledge Explorations in Sustainability and Governance. pp. 181-193.

Madrid-Lopez, C., Giampietro, M., 2014. Water grammar. In: Giampietro, M., Aspinall, R.J., Ramos-Martin, J., Bukkens, S.G.F. (Eds.), Resource Accounting for Sustainability Assessment. The Nexus between Energy, Food, Water and Land Use. Taylor \& Francis Group, Routledge.

Madrid-López, C., Giampietro, M., 2015. The water metabolism of socio-ecological systems: reflections and a conceptual framework. J. Ind. Ecol. 19, 853-865.

Madrid, C., Cabello, V., Giampietro, M., 2013. Water-use sustainability in socioecological systems: a multiscale integrated approach. Bioscience 63, 14-24 https://doi. org/10.1525/bio.2013.63.1.6

MAGAP, 2015. Land Use and Lan Cover Map. Years 2014-2015. 1:25,000 Scale. Ministry of Agriculture, Livestock, Aquaculture and Fisheries. 
MAGAP, 2013. Plan Nacional de Riego y Drenaje 2012-2017. Ministerio de Agricultura, Ganadería, Acuacultura y Pesca. Subsecretaría de Riego y Drenaje.

Molina, A., Vanacker, V., Brisson, E., Mora, D., Balthazar, V., 2015. Long-term effects of climate and land cover change on freshwater provision in the tropical Andes. Hydrol. Earth Syst. Sci. Discuss. 12, 5219-5250 https://doi.org/10.5194/ hessd-12-5219-2015.

Morán-Tejeda, E., Bazo, J., López-Moreno, J.I., Aguilar, E., Azorín-Molina, C., Sanchez-Lorenzo, A., Martínez, R., Nieto, J.J., Mejía, R., Martín-Hernández, N., Vicente-Serrano, S.M., 2015. Climate trends and variability in Ecuador (1966-2011). Int. J. Climatol. 3855, 3839-3855 https://doi.org/10.1002/joc.4597.

Nehring, R., 2012. Politics and Policies of Food Sovereignty in Ecuador: New Directions or Broken Promises?. International Policy Centre for Inclusive Growth.

Olen, B., Wu, J., Langpap, C., 2016. Irrigation decisions for major west coast crops: water scarcity and climatic determinants. Am. J. Agric. Econ. 98, 254-275 https:// doi.org/10.1093/ajae/aav036.

Perez Neira, D., 2016. Energy sustainability of Ecuadorian cacao export and its contribution to climate change. A case study through product life cycle assessment. J. Clean. Prod. 112, 2560-2568 https://doi.org/10.1016/j.jclepro.2015.11.003.

República del Ecuador, 2008. Constitución del Ecuador. http://www.asambleanacional. gov.ec/documentos/constitucion_de_bolsillo.pdfAccessed 26 August 2015.

Rockström, J., Falkenmark, M., Allan, T., Folke, C., Gordon, L., Jägerskog, a., Kummu, M., Lannerstad, M., Meybeck, M., Molden, D., Postel, S., Savenije, H., Svedin, U., Turton, a., Varis, O., 2014. The unfolding water drama in the Anthropocene: towards a resilience based perspective on water for global sustainability. Ecohydrology 1261, 1249-1261 https://doi.org/10.1002/eco.1562.

Rodrigues, D.B.B., Gupta, H.V., Mendiondo, E.M., 2014. A blue/green water-based accounting framework for assessment of water security. Water Resour. Res. 50, 7187-7205 https://doi.org/10.1002/2013WR014274.

Rodríguez-Díaz, J.A., Pérez-Urrestarazu, L., Camacho-Poyato, E., Montesinos, P., 2011. The paradox of irrigation scheme modernization: more efficient water use linked to higher energy demand. Spanish J. Agric. Res. 9, 9 https://doi.org/https:// doi.org/10.5424/sjar/20110904-492-10.

Salmoral, G., Willaarts, B.A., Garrido, A., Guse, B., 2017. Fostering integrated land and water management approaches: evaluating the water footprint of a Mediterranean basin under different agricultural land use scenarios. Land Use Pol. 61, 24-39.

SENPLADES, 2013. Good Living National Plan 2013-2017. A Better World for Every One. Summarized Version National Secretariat of Planning and Development.

Serrano-Tovar, T., Cadillo-Benalcazar, Z., Diaz-Maurin, F., Kovacik, Z., Madrid-López, C., Giampietro, M., Aspinall, R.J., Ramos-Martin, J., Bukkens, S.G.F., 2014. The republic of Mauritius. In: Giampietro, M., Aspinall, R.J., Ramos-Martin, J., Bukkens, S.G.F. (Eds.), Resource Accounting for Sustainability: the Nexus between Energy, Food, Water and Land Use, Routledge Explorations in Sustainability and Governance. pp. 163-180.

Steffen, W., Richardson, K., Rockstrom, J., Cornell, S.E., Fetzer, I., Bennett, E.M., Biggs, R., Carpenter, S.R., de Vries, W., de Wit, C.A., Folke, C., Gerten, D., Heinke, J., Mace, G.M., Persson, L.M., Ramanathan, V., Reyers, B., Sorlin, S., 2015. Planetary boundaries: guiding human development on a changing planet. Science (80-. ) 347, 1259855 https://doi.org/10.1126/science. 1259855.

Vanham, D., 2015. Does the water footprint concept provide relevant information to address the water-food-energy-ecosystem nexus?. Ecosyst. Serv. 17, 298-307 https://doi.org/10.1016/j.ecoser.2015.08.003.

Veettil, A.V., Mishra, A.K., 2016. Water security assessment using blue and green water footprint concepts. J. Hydrol. 542, 589-602 https://doi.org/10.1016/j.jhydrol. 2016.09.032.

Vicente-Serrano, S.M., Aguilar, E., Martínez, R., Martín-Hernández, N., Azorin-Molina, C., Sanchez-Lorenzo, A., El Kenawy, A., Tomás-Burguera, M., Moran-Tejeda, E., López-Moreno, J.I., Revuelto, J., Beguería, S., Nieto, J.J., Drumond, A., Gimeno, L., Nieto, R., 2016. The complex influence of ENSO on droughts in Ecuador. Clim. Dyn. 48, 1-23 https://doi.org/10.1007/ s00382-016-3082-y. 